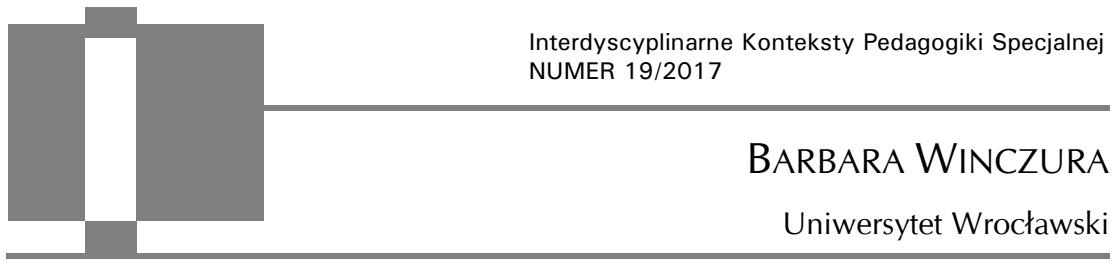

\title{
Od wczesnych zwiastunów autyzmu po przywiązanie - rozwój relacji społecznych dzieci ze spektrum autyzmu w kontaktach z bliskimi
}

\begin{abstract}
Barbara Winczura, Od wczesnych zwiastunów autyzmu po przywiąanie rozwój relacji społecznych dzieci ze spektrum autyzmu w kontaktach z bliskimi [From early signs of autism to attachment relationship - development of social relationships of children with autism spectrum disorders in contacts with relatives]. Interdyscyplinarne Konteksty Pedagogiki Specjalnej, nr 19, Poznań 2017. Pp. 69-94. Adam Mickiewicz University Press. ISSN 2300-391X

Autism is a vast developmental disorder with significant delays and problems in participation in alternate social interactions. Studies show that nearly half of population with autism participation social life, although their profile of emotional and social deficits remains highly diversified. Difficulties in social sphere include a limited capacity and ability to recognize, to understand and to engage in human contact and interpersonal communication. Parents/guardians relatives are the first observers of disturbing behaviors of a child and the first initiators of building a close relationship with his offspring. Their observations are the determinants of the criteria of early detection of autism spectrum disorders. The biggest problem for parents is the inability of their children with autism to showing affection. The goal of this article is to show the profile of the development of social relationships of children with autism in contacts with relatives and analysis of conditions in the attachment relationship the child - parent in this group of disorders.
\end{abstract}

KEY WORDS: autism spectrum disorders, early signs of autism, early socialemotional development, relationships with loved ones, autism and attachment 


\section{Wprowadzenie}

Zgodnie ze współczesnymi kryteriami diagnostycznymi autystyczne spektrum zaburzeń charakteryzują jakościowe zaburzenia zdolności uczestniczenia $\mathrm{w}$ naprzemiennych interakcjach społecznych ${ }^{1}$. Podkreśla się, iż w populacji osób ze spektrum autyzmu obserwuje się duże zróżnicowanie relacji emocjonalno-społecznych wyrażanych $\mathrm{w}$ kontakcie $\mathrm{z}$ bliskimi ${ }^{2}$. Badania pokazują, że prawie połowa osób $\mathrm{z}$ autyzmem $\mathrm{w}$ różnej formie uczestniczy w życiu społecznym ${ }^{3}$, choć ich profil deficytów emocjonalno-społecznych pozostaje wysoce zróżnicowany ${ }^{4}$. Upośledzenie sfery społecznej $\mathrm{w}$ tej populacji jest wieloaspektowe. Obejmuje ograniczone możliwości i zdolności rozpoznawania, rozumienia i zaangażowania się w kontakt z drugim człowiekiem oraz zaburzone umiejętności społeczne pozwalające wchodzić, inicjować, angażować się w prawidłowe interakcje społeczne i komunikację międzyludzką̧5. Charakterystyczne objawy nieprawidłowości $w$ sferze nawiązywania relacji emocjonalno-społecznych u dzieci ze spektrum autyzmu pojawiają się stopniowo i przyjmują różne natężenie w czasie. Zdolność do tworzenia bliskich relacji uznaje się za proces ciągły, ale i dyna-

${ }^{1}$ E. Pisula, Od badań mózgu do praktyki psychologicznej. AUTYZM, Wydawnictwo GWP, Sopot 2012, s. 30-40; S. Ozonoff, G. Dawson, J.C. McPartland, Wysokofunkcjonujace dzieci ze spektrum autyzmu. Poradnik dla rodziców, Wydawnictwo Uniwersytet Jagielloński, Kraków 2015, s. 213-243.

${ }^{2}$ K. Markiewicz, Charakterystyka zmian w rozwoju umystowym dzieci autystycznych, Wydawnictwo Uniwersytetu Marii Curie-Skłodowskiej, Lublin 2007, s. 88-89.

${ }^{3}$ M. Talarowska i in., Psychologiczne koncepcje rozwoju autyzmu, [w:] Autyzm epidemiologia, diagnoza i terapia, red. T. Pietras, A. Witusik, P. Gałecki, Wydawnictwo Continuo, Wrocław 2010, s. 111.

${ }^{4}$ C. Saarni, Kompetencja emocjonalna i samoregulacja w dzieciństwie, [w:] Rozwój emocjonalny a inteligencja emocjonalna, red. P. Salovey, D. Sluyter, Dom Wydawniczy REBIS, Poznań 1999, s. 80; E. Pisula, Małe dziecko z autyzmem. Diagnoza i Terapia, Gdańskie Wydawnictwo Psychologiczne, Gdańsk 2005, s. 32.

${ }^{5}$ A.J. Cotugno, Terapia grupowa dla dzieci z zaburzeniami ze spectrum autyzmu. Rozwijanie kompetencji i umiejętności społecznych, Wydawnictwo Fraszka Edukacyjna, Warszawa 2011, s. 43. 
miczny ${ }^{6}$. Rodzice/bliscy opiekunowie stają się pierwszymi obserwatorami niepokojących zachowań swojego dziecka, ale i pierwszymi inicjatorami budowania bliskich relacji ze swoim potomstwem. Podawane przez nich spostrzeżenia, stanowią wyznaczniki dla kryteriów wczesnego wykrywania zaburzeń ze spektrum autyzmu. Największym problemem rodziców jest niezdolność dzieci z autyzmem do okazywania przywiązania, a nawet do odróżniania bliskich osób od nieznajomych. Rozwój przywiązania w tej grupie zaburzeń w znacznym stopniu jest warunkowany poziomem rozwoju emocjonalno-społecznego dziecka. Należy jednak podkreślić, że zakresie ekspresji uczuciowych więzi z rodzicami obserwuje się wewnętrzne zróżnicowanie w całej populacji osób ze spektrum autyzmu. Różnice w ekspresji przywiązania nie są równoznaczne ani z brakiem zdolności do tworzenia więzi emocjonalnych, ani z określonym charakterem więzi ${ }^{7}$.

\section{Pierwsze kontakty dziecka z bliskimi a zwiastuny autyzmu}

Zaburzenia zdolności społecznych u dzieci ze spektrum autyzmu bywają widoczne bardzo wcześnie. Niektóre niepokojące symptomy ujawniają się w rozwoju dziecka, zanim jeszcze uzyska ono diagnozę autyzmu. Pierwsze więzi społeczne dziecka kształtują się $\mathrm{w}$ kontakcie $\mathrm{z}$ matką, dlatego zaburzenia $\mathrm{w}$ tej relacji są oceniane jako bardzo ważny sygnał zapowiadający rozwój autyzmu8. Trud-

${ }^{6}$ S.L. Greenspan, S. Wieder, Dotrzeć do dziecka z autyzmem. Jak pomóc dzieciom nawiązywać relacje, komunikować się i myśleć. Metoda Floortime, Wydawnictwo Uniwersytetu Jagiellońskiego, Kraków 2014, s. 27; S.J. Rogers, G. Dawson, Early Start Denver Model dla małych dzieci z autyzmem. Wspieranie komunikacji, uczenia się i rozwoju spotecznego, Wydawnictwo Fundacja rozwiązać Autyzm, Warszawa 2015, s. 4-8.

${ }^{7}$ E. Pisula, Autyzm i przywiazanie. Studia nad interakcjami dzieci $z$ autyzmem $i$ ich matek, Gdańskie Wydawnictwo Psychologiczne, Gdańsk 2003, s. 51.

${ }^{8} \mathrm{H}$. Jaklewicz, Autyzm dziecięcy, [w:] Psychiatria wieku rozwojowego, red. A. Popielarska, M. Popielarska, Wydawnictwo Lekarskie PZWL, Warszawa 2000, s. 118. 
ności w ekspresji emocji, brak lub zaburzony kontakt społeczny u małych dzieci traktuje się jako sygnał ostrzegawczy oraz jeden z pierwszych wskaźników zaburzeń wyrażania, rozumienia emocji oraz budowania właściwych relacji społecznych z innymi ludźmi, które pojawiają się w przyszłości $w$ tej populacji osób. Ponadto problem ten stosunkowo wcześnie zauważają rodzice, gdyż powoduje on szczególne trudności w kontakcie z dzieckiem?9.

Badania dotyczące pierwszych interakcji matka - dziecko, wskazują, że zdrowy noworodek jest wyposażony w umiejętność dostrajania się do sytuacji społecznych, szczególnie w zakresie synchronizacji interakcji, naśladowania, poszukiwania kontaktu wzrokowego $\mathrm{w}$ reakcji na głos matki. Już od samego urodzenia zdrowe niemowlę preferuje ludzkie twarze i dźwięki związane z mową. Około 6. tygodnia życia pojawia się tzw. uśmiech społeczny, a około 6-8. miesiąca niemowlę potrafi odróżnić twarze osób bliskich i reaguje lękiem na twarze osób obcych ${ }^{10}$.

Z wielu obserwacji rodziców wynika, że już w pierwszych miesiącach życia dziecka niepokojący jest brak okazywania, że dziecku zależy na kontakcie z matką, bliskim opiekunem ${ }^{11}$. Ma słaby kontakt wzrokowy, brak mimiki twarzy i typową nieumiejętność przyjęcia postawy ciała wyrażającej gotowość i pragnienie, aby ktoś wziął je na ręce ${ }^{12}$. Najczęściej preferuje samotność, nie jest zainteresowane kontaktem fizycznym z inną osobą, wyraża obojętność, a nawet niechęć do takiego kontaktu. Zachowuje się tak, jakby osoby $w$ rodzinie były poza obszarem jego zainteresowań ${ }^{13}$. Nie reagu-

${ }^{9}$ E. Pisula, Mate dziecko..., s. 67-68.

${ }^{10}$ G. Jagielska, Objawy autyzmu dziecięcego, [w:] Autyzm i zespót Aspergera, red. J. Komender, G. Jagielska, A. Bryńska, Wydawnictwo Lekarskie PZWL, Warszawa 2009 , s. 36.

11 T. Gałkowski, Usprawnianie dziecka autystycznego w rodzinie, Wydawnictwo PTWK, Warszawa 1980.

12 L. Wing, Związek między zespołom Aspergera i autyzmem Kannera, [w:] Autyzm i zespót Aspergera, red. U. Frith, Wydawnictwo Lekarskie PZWL, Warszawa 2005, s. 117.

${ }^{13}$ E. Pisula, Wspomaganie osób z zaburzeniami należącymi do autystycznego spektrum $w$ perspektywie psychopatologii rozwojowej, [w:] Psychologia rozwoju czlowieka, red. J. Trempała, Wydawnictwo PWN, Warszawa 2011, s. 449. 
je na widok matki emocjonalnym ożywieniem, nie odpowiada uśmiechem na uśmiech ani się nie przytula. Kiedy bliska osoba trzyma je na rękach - jest jakby "odległe”, "zamknięte w sobie”, „nieobecne”. Trzymane $\mathrm{w}$ ramionach może sztywnieć lub robić się wiotkie, może też aktywnie bronić się przed przytulaniem lub wzięte na ręce nie wchodzi $w$ interakcje $z$ opiekunem ${ }^{14}$. Na ogół nie lubi zabaw z baraszkowaniem, łaskotaniem. Dziecko może nawet nie reagować radosnym ożywieniem na widok zbliżającej się matki lub pozostać obojętne, gdy ona oddala się od niego. Może sprawiać wrażenie, jakby nie potrzebowało obecności i uwagi bliskich osób, często jest nadmiernie spokojne albo pobudzone. Większość dzieci $\mathrm{z}$ autyzmem we wczesnym okresie życia nie przejawia tzw. lęku separacyjnego, związanego z rozdzielaniem z osobami znaczącymi, bliskimi, najczęściej matką. Okazują wyraźne zadowolenie, gdy są pozostawione same sobie i zachowują się tak, jakby nie było wokół nich ludzi ${ }^{15}$.

Choć niektóre z dzieci demonstrują swoje emocjonalne przywiązanie do swoich opiekunów, to jednak nie reagują na okazywaną im miłość i uczucia w sposób, jakiego osoby te oczekują. Z wypowiedzi rodziców wynika, że ich dzieci niechętnie otwierają swoje ramiona, by się przytulić w momencie bólu, niepokoju, zagrożenia i poszukać u nich pocieszenia, a nawet sprawiają wrażenie nieświadomych, że jest to w ogóle możliwe. Rodziców niepokoi fakt, że nie czynią rozróżnienia pomiędzy nimi a przedmiotami, którymi się fascynują i że wolą kontakt z ulubioną zabawką niż fizyczny, bliski kontakt z rodzicem ${ }^{16}$. Zazwyczaj dziecko dąży do kontaktu z przedmiotami i mechanizmami, odrzucając bliskość człowieka, gdyż przedmioty nieożywione nie budzą najważniejszych, a więc i najsil-

14 J. Morrison, DSM-5 Bez Tajemnic. Praktyczny przewodnik dla klinicystów, Wydawnictwo Uniwersytetu Jagiellońskiego, Kraków 2016, s. 41.

15 G. Jagielska, op. cit., s. 38; Morrison J., op. cit., s. 41-42; J. Ball, Autyzm a wczesna interwencja. Rzeczowe pytania, życiowe odpowiedzi. Wydawnictwo Harmonia Universalis, Gdańsk 2016, s. 55-56.

16 P. Randall, J. Parker, Autyzm. Jak pomóc rodzinie, Gdańskie Wydawnictwo Psychologiczne, Sopot 2010, s. 99, 146. 
niejszych dla niego uczuć: więzi, radości z emocjonalnego kontaktu, poczucia bezpieczeństwa, bliskości. Wskutek nadwrażliwości na bodźce zewnętrzne oraz przeciążenia emocjonalnego dziecko selektywnie wycofuje się z kontaktów z bliskimi osobami, woląc przedmioty martwe, emocjonalnie obojętne, a więc przy tym przewidywalne i dla niego bezpieczne. Jednym z najistotniejszych tego typu mechanizmów jest brak poszukującego, intencjonalnego spoglądania na ludzi i dążenia do kontaktu $\mathrm{z}$ nimi. Objaw ten stopniowo narasta i stanowi o istocie autyzmu oraz jest jego cechą osiową ${ }^{17}$.

$\mathrm{U}$ małych dzieci z podejrzeniem autyzmu obserwuje się duże zróżnicowanie wyrażanych emocji w kontakcie społecznym z najbliższymi. Od stanów obojętności, „obcości”, ignorancji, reakcji panicznego lęku w sytuacji odsunięcia dziecka od matki po silne i bogate emocje świadczące o przywiązaniu dziecka do bliskich mu osób18. Zdolność do silnych emocji może wyrazić się np. uczuciem tęsknoty za bliskim opiekunem i domem w sytuacji chwilowej lub dłuższej rozłąki ${ }^{19}$. Reakcje tego typu należą jednak do rzadkości. Członkom rodziny trudno rozpoznać i zrozumieć te stany emocjonalne, tym bardziej, gdy dziecko jest niemówiące, przy dodatkowo zaburzonej mimice, gestach, kontakcie wzrokowym, postawie ciała nie umie precyzyjnie informować bliskich, otoczenie o swoich przeżyciach i potrzebach. Dodatkowo ma znacznie ograniczone możliwości wyrażania emocji. Posługuje się czymś w rodzaju specjalnego, prywatnego kodu komunikacyjnego. Czyni to w sposób idiosynkratyczny, nieuniwersalny, często oparty na nieistotnych skojarzeniach, utworzonych w wyniku jednego przypadkowego zdarzenia i następnie schematycznie utrwalonych ${ }^{20}$.

17 H. Olechnowicz, R. Wiktorowicz, Dziecko z autyzmem. Wyzwalanie potencjału rozwojowego, Wydawnictwo PWN, Warszawa 2012, s. 10-11; M. Piszczek, Autyści. Indywidualne i grupowe metody terapii. Zajęcia adresowane dla Rodziców, Wydawnictwo STECKO, Warszawa 2014, s. 64.

18 K. Markiewicz, op. cit., s. 89; E. Pisula, Autyzm i przywiązanie..., s. 51.

19 A. Rynkiewicz, Zespót Aspergera. Inny mózg. Inny umyst, Wydawnictwo Harmonia Gdańsk 2009, s. 50.

${ }^{20}$ L. Wing, op. cit., 116. 
Czasami pojawiają się odmienne, wręcz specyficzne formy nawiązywania kontaktu przez dzieci ze spektrum autyzmu z bliskimi. Mogą pojawić się zwłaszcza w stosunku do wybranej osoby, która spędza z nim najwięcej czasu, opiekuje się z nim, bawi się z nim czy też spełnia wiele jego potrzeb i pragnień. Jest to o tyle zasadne, gdyż inni dorośli (np. starsze rodzeństwo) nie wywołują u dziecka w takim samym stopniu poczucia bliskości lub bezpieczeństwa, gdy czują zagrożone lub czegoś potrzebują ${ }^{21}$. Zaobserwowano, że niektóre $\mathrm{z}$ nich wyrażają potrzebę kontaktu, ustawiając się bokiem, a nawet plecami do osoby zwracającej się do dziecka. Niekiedy posługują się przedmiotami dla siebie znaczącymi, tzw. talizmanami (np. sznurkiem, kredką, klockiem) gdy chcą wyrazić swoją potrzebę, okazać uczucia czy też osiągnąć swój cel22. Ciągną, szarpią, szczypią, stukają swoim ulubionym przedmiotem bliską osobę, pozwalają go dotknąć, potrzymać, powtarzają schematycznie to samo pytanie, zwrot (np. „jak się masz?”), domagając się na nie stałej odpowiedzi („ok., dobrze się mam”), głaszczą włosy, stałe części ciała, pozwalają się zbliżyć do siebie, a nawet niekiedy podają rękę na powitanie czy się przytulają. Zwykle ekspresja emocjonalna dziecka w takich kontaktach jest dziwaczna, nieczytelna, brak w niej precyzji, subtelności, całej gamy gestów, mimiki, postawy ciała. Dziecko wysyła wiele sprzecznych, nieczytelnych sygnałów. Zdarzają się sytuacje, że zupełnie obcy człowiek może zostać przytulony, pogłaskany, a niezadowolenie wobec bliskiego członka rodziny może być wyrażone w sposób nieadekwatny do sytuacji ${ }^{23}$. Zdecydowanie nie potrafią dostosować własnych zachowań do reakcji i zachowań innych ${ }^{24}$, natomiast posługują się atypowymi formami nawiązywania kontaktu z bliskimi osobami. Dodatkowo sprawę pogarsza fakt, że

21 S.L. Greenspan, S. Wieder, op. cit., 26-27.

22 A. Rybka, A. Garncarz, Stymulowanie rozwoju emocjonalnego u osób z autyzmem, [w:] Kompleksowe wspomaganie rozwoju uczniów z autyzmem i zaburzeniami pokrewnymi, red. J. Kossewska, Oficyna Wydawnicza „Impuls”, Kraków 2009, s. 143.

23 T. Attwood, Zespót Aspergera, Wydawnictwo Zysk i S-ka, Poznań 2006, s. 50.

${ }^{24}$ R.H. Schaffer, Psychologia dziecka, Wydawnictwo PWN, Warszawa 2009, s. 178 . 
dzieci ze spektrum autyzmu nie odbierają sygnałów niewerbalnych, które są przecież istotną częścią komunikacji. Umyka im ton głosu, wyraz twarzy, mowa ciała, czyli te wskazówki, które prawidłowo rozwijające się dzieci uczą się rozpoznawać w codziennych kontaktach z ludźmi ${ }^{25}$.

Szczególną uwagę otoczenia zwraca unikanie kontaktu wzrokowego przez dziecko. Rodzice wskazują, że dziecko unika go aktywnie lub nie potrafi go utrzymać. Może zasłaniać oczy, odwracać twarz, kiedy jest wołane, obserwować obiekty kątem oka, patrzeć nieobecnym wzrokiem, jakby w "pustą przestrzen”", „przez osobę"26. Dziecko jest $w$ niewielkim stopniu zainteresowane twarzą ludzką, widokiem i głosem matki ${ }^{27}$. Nie fiksuje wzroku na twarzy matki, nie wodzi za nią wzrokiem, nie reaguje emocjonalnym ożywieniem na jej widok, szczególnie na jej spojrzenie, uśmiech czy gesty ${ }^{28}$. Charakterystyczna jest zaburzona mimika twarzy („maskowatość"), brak ciepłej, radosnej ekspresji towarzyszącej spojrzeniu, rzadki uśmiech i typowa nieumiejętność przyjęcia postawy ciała, wyrażającej gotowość i pragnienie, aby ktoś wziął je na ręce ${ }^{29}$. Uśmiech społeczny pojawia się rzadko, czasami wygląda sztucznie, sztywno, jakby był doklejony ${ }^{30}$. Obserwuje się przy tym krótki czas patrzenia na ludzi ${ }^{31}$. Dziecko rzadko przenosi spojrzenie z przedmiotu na twarz osoby. Badania, w których analizowano kierunek patrzenia wskazują, że dzieci z tym zaburzeniem rzadziej patrzą w oczy oglądanych postaci, częściej natomiast śledzą ich poruszające się usta i resztę ciała ${ }^{32}$. Dziecko nie reaguje na wołanie po imieniu

25 J. Ball, op. cit., s. 36.

${ }^{26}$ G. Jagielska, op. cit., s. 38 .

27 J. Błeszyński, Autyzm a niepetnosprawność intelektualna i opóźnienie w rozwoju. Skala Oceny Zachowań Autystycznych, Wydawnictwo Harmonia Universalis, Gdańsk 2011, s. 61; D. Senator, Przejawy autyzmu w pierwszym roku życia, „Pediatria Polska” 2006, nr 2, s. 128.

${ }^{28}$ H. Jaklewicz, op. cit., s. 118.

${ }^{29}$ L. Wing, op. cit., s. 117.

30 E. Pisula, Mate dziecko..., s. 32; H. Jaklewicz, op. cit., s. 118-119.

31 P. Randall, J. Parker, op. cit., s. 99, 146.

32 E. Pisula, Wspomaganie osób..., s. 448. 
przy zwracaniu uwagi na inne dźwięki w otoczeniu. Czasami imię dziecka musi być wielokrotnie powtórzone, zanim zwróci ono uwagę na wypowiadającą je osobę ${ }^{33}$. Widocznym deficytem są także trudności $\mathrm{z}$ imitowaniem stanów emocjonalnych innych osób. Dziecko nie potrafi dzielić radości, smutku, bólu, strachu z innymi osobami. Typowy jest także brak ekspresji wokalno-emocjonalnej w rodzaju "ooo", „uu” oraz znikomy lub nieobecny repertuar gestów interakcyjnych, np. machanie ręką "pa-pa"34. Towarzyszy temu brak właściwej gestykulacji i wyrażania emocji za pomocą postawy. W rezultacie dominuje ograniczony repertuar zachowań społecznych, łączących spojrzenie, ekspresję mimiczną, ton głosu i gestykulację ${ }^{35}$.

Dziecko angażuje się $\mathrm{w}$ relacje głównie $\mathrm{z}$ członkami rodziny, dlatego że chce zaspokoić swoją potrzebę, np. chce dostać zabawkę, często wykorzystując przy tym dłoń osoby stojącej obok (traktuje rękę dorosłego jako narzędzie do zaspokojenia swoich potrzeb) ${ }^{36}$. Nie potrafi uczestniczyć w normalnych interakcjach społecznych, opartych na schemacie dawania - brania. Niepokojący jest brak zdolności do naprzemiennego uczestnictwa w dialogu. Nawet jeżeli zdarza się, że dziecko inicjuje kontakt z uczestnikiem interakcji, to rzadko potrafi ten kontakt podtrzymać ${ }^{37}$. Nie potrafi używać mowy ciała lub innych niewerbalnych zachowań do komunikowania się, np. uśmiechów lub kiwnięć głową, za pomocą których większość z nas wyraża aprobatę ${ }^{38}$. Małe dziecko na tym etapie rozwoju autyzmu jest już nieświadome, że ludzie komunikują się, wymieniają myśli, wykorzystując spojrzenia, ruch ciał i dźwięki mowy. Widzi te ruchy i słyszy dźwięki mowy, lecz nie wie, że kryje

33 D. Senator, op. cit., s. 129.

${ }^{34}$ M. Skórczyńska, Wczesne diagnozowanie autyzmu - perspektywy i dylematy, [w:] Autyzm Na granicy zrozumienia, red. B. Winczura, Oficyna Wydawnicza "Impuls", Kraków 2009, s. 48.

35 E. Pisula, Wspomaganie osób..., s. 449.

36 H. Jaklewicz, op. cit., s. 119.

37 E. Pisula, Stres rodzicielski zwiazany z wychowaniem dzieci autystycznych $i$ z zespołem Dawna, „Psychologia Wychowawcza” 1993, nr 1, s. 45; M. Piszczek, op. cit., s. 12-13.

38 J. Morrison, op. cit., s. 41. 
się za nimi jakieś znaczenie, jakaś wiadomość do odczytania i wykorzystania ${ }^{39}$.

Często rodzice podają, że ich dziecko jest zbyt spokojne, ciche, wycofane z kontaktów, mało aktywne, wręcz apatyczne i niezainteresowane otoczeniem, zabawą z rodzeństwem i innymi dziećmi ${ }^{40}$. Bardzo rzadko wykazuje zamierzone ukierunkowanie uwagi innych osób, nie tworzy wspólnego pola uwagi, nie wymienia komunikatów z rodzicem, rodzeństwem, co jest szczególnie zauważalne podczas zabawy. Pod koniec pierwszego roku życia uwagę otoczenia może zwracać uwagę brak zabaw związanych $\mathrm{z}$ naśladowaniem, a później brak zabaw „na niby” związanych z udawaniem i używaniem przedmiotów w sposób symboliczny. Zabawy najczęściej są samotne, bez kontaktu z ludźmi, zwykle o charakterze sensomotorycznym i/lub rytualnym, pozbawione wyobraźni. Małe dziecko może nieustannie ustawiać przedmioty w szereg, w sterty lub kręcić przedmiotami. Może układać, porządkować zabawki stale $\mathrm{w}$ ten sam sposób, gromadzić określone przedmioty, układać patyczki, klocki według określonego, powtarzalnego schematu ${ }^{41}$.

Stopniowo, wraz z rozwojem, $\mathrm{u}$ dziecka pojawiają się kolejne objawy zaburzeń ze spektrum autyzmu w obszarze komunikacji, wyrażaniu i rozumieniu emocji oraz w nawiązywaniu relacji społecznych ${ }^{42}$. Najczęściej sygnalizowane spostrzeżenia przez rodziców/bliskich opiekunów tych dzieci to:

- nie umie nawiązać bliskich relacji z członkami w rodzinie,

39 S.J. Rogers, G. Dawson, L.A. Vismara, Metoda wczesnego startu dla dziecka z autyzmem (ESDM). Jak wykorzystać codzienne aktywności, aby pomóc dzieciom tworzyć więzi, komunikować się i uczyć, Wydawnictwo Uniwersytetu Jagiellońskiego, Kraków 2015, s. 68.

${ }^{40}$ E. Pisula, Autyzm u dzieci. Diagnoza, klasyfikacja, etiologia, Wydawnictwo PWN, Warszawa 2000, s. 117.

${ }^{41}$ E. Wiekiera, Strategia postępowania $z$ dziećmi autystycznymi, Przekład $z$ "Engagement", Poradnik praktyczny dla rodziców, Wydawnictwo Krajowe Towarzystwo Autyzmu Oddział w Krakowie, Kraków 1995, s. 13; G. Jagielska, op. cit., s. 40.

42 B. Nason, Porozmawiajmy o autyzmie Przewodnik dla rodziców i specjalistów, Wydawnictwo Uniwersytetu Jagiellońskiego, Kraków 2017, s. 321-234. 
- nie wita się ani nie reaguje spontanicznie na rodzica/opiekuna, - słabo wyraża emocje albo czyni to w sposób nieodpowiedni, typowy tylko dla siebie, rzadko dzieli emocje z bliskimi,

- nie dostrzega i nie odczytuje emocji innych, bliskich osób w otoczeniu, nie dzieli z nimi radości, smutku, strachu ${ }^{43}$,

- nie posługuje się typowymi gestami w celu nawiązania kontaktów społecznych,

- ma zubożoną mimikę twarzy, zwłaszcza w interakcjach z matką,

- nie rozumie „przestrzeni osobowej” - podchodzi zbyt blisko lub ucieka zbyt daleko od osób w swoim najbliższym środowisku,

- nie umie inicjować zabawy z zabawkami, instruowany przez rodzica potrafi bawić się prostymi przedmiotami, fragmentami zabawek, rzadko jednak czyni to spontanicznie w interakcji $\mathrm{z}$ innymi ${ }^{44}$,

- nie interesuje się w sposób naturalny dziećmi (rówieśnikami) lub nawet może demonstracyjnie ich unikać,

- nie wyraża gotowości do wspólnych zabaw z rodzicami, rodzeństwem, nie interesuje się zabawą społecznąa5,

- ma ograniczone zdolności naśladowania i nie uczestniczy w zabawach z udawaniem z innymi dziećmi, obserwuje się rutynowe wzorce, sztywność, brak pomysłowości i wyobraźni w zabawie ${ }^{46}$,

- kontakty z bliskimi przybierają nietypową formę, głównie jako przywiązanie do rutyny, która jest związana z określoną oso-

43 A. Wolski, Diagnoza autyzmu u małego dziecka - implikacje do pracy w rodzinie, "Rewalidacja" Czasopismo dla nauczycieli i terapeutów" 2010, nr 2 (28), s. 24; A. Wolski, Dominujace $i$ drugorzędne kryteria diagnostyczne - ich struktura u dzieci, u których zdiagnozowano autyzm, [w:] Edukacja i Rehabilitacja osób niepetnosprawnych OBLICZA TERAPII, Pedagogika Specjalna - koncepcje i rzeczywistość, tom IX, red. T. Żółkowska, M. Wlazło, Wydawnictwo Naukowe WH MINERWA, Szczecin 2013, s. 323-347.

44 S.L. Greenspan, S. Wieder, op. cit., s. 28.

45 A.J. Cotugno, op. cit., s. 45.

46 E. Pisula, Autyzm u dzieci..., s. 118; E. Pisula, Wspomaganie osób..., s. 447. 
bą, jej zachowaniem, formami komunikacji, zaspokajaniem potrzeb dziecka, rzadko natomiast z przywiązaniem emocjonalnym ${ }^{47}$,

- nie potrafi dzielić się swoimi zainteresowaniami i uczuciami z innymi ludźmi ani tworzyć odpowiednich dla swojego wieku relacji z rówieśnikami,

- nie umie wykorzystać zachowań niewerbalnych (takich jak kontakt wzrokowy, mimika, postawa ciała i gestykulacja) do regulowania kontaktów społecznych ${ }^{48}$.

- nie rozpoznaje i nie rozumie potrzeby wymiany społecznej z innymi ludźmi oraz jej zależności,

- ma trudności w zrozumieniu i docenianiu myśli i emocji innych (deficyt teorii umysłu) oraz nie wykazuje empatii ani troski o uczucia i emocje innych ${ }^{49}$,

- nie szuka pocieszenia u rodziców ani u nikogo innego (rodzeństwa, dziadków),

- nie ma wyobraźni społecznej i nie odwzajemnia relacji społecznych ${ }^{50}$.

W badaniach prowadzonych przez Geraline Dawson i Julie Osterling ${ }^{51}$ na podstawie analizy nagrań wideo wykonanych przez rodziców zauważono, że pomiędzy 8. a 12. miesiącem życia dzieci te spędzają mniej czasu, przyglądając się innym ludziom, słabiej reagują, gdy ich bliscy usiłują zwrócić ich uwagę (np. wołając po imieniu) i nie wykonują wczesnych gestów (takich ja wskazywanie), którymi dzieci się zwykle posługują i które pomagają im czynić postępy w komunikacji społecznej. Sposób, w jaki dzieci te doświadczają kontaktu ze swoim otoczeniem, bliskimi osobami, różni

${ }^{47}$ E. Wiekiera, op. cit., s. 13.

48 E. Pisula, op. cit., s. 447.

${ }^{49}$ S. Baron-Cohen, Mindblindness: An essay on autism and theory of mind, Cambridge Mass., MIT Press, London 1995.

50 A. J. Cotugno, op. cit., s. 45.

51 G. Dawson, J. Osterling, Early recognition of children with autism: A stady of first birthday home videotapes, "Journal of Autism and Developmental Disorders" 1994, nr 24, s. 247-257. 
się znacząco od typowego dla ich rówieśników. Spędzają mniej czasu, koncentrując się na głównie na przedmiotach i mają zdecydowanie mniejsze doświadczenie w zakresie komunikacji ${ }^{52}$.

Za najbardziej znaczące symptomy dla wczesnego rozpoznawania zaburzeń ze spektrum autyzmu uznaje się deficyty emocjonalno-społeczne i zaburzenia w komunikacji społecznej. Wczesna ocena zaburzeń u małych dzieci ma zazwyczaj charakter introspektywny i opiera się głównie na informacjach uzyskanych od rodziców/bliskich opiekunów tych dzieci. Przeciętnie rodzice zaczynają zauważać problemy rozwojowe około 19. miesiąca życia dziecka, niewielka grupa widzi różne nieprawidłowości przed ukończeniem pierwszego roku życia, a znaczna większość dopiero w wieku dwóch lat ${ }^{53}$. Choć przyjmuje się, że spostrzeżenia rodziców mają charakter subiektywny, obarczony błędem emocjonalnego zaangażowania, niekiedy nawet zniekształcony przez miniony czas i wiedzę o ewentualnych mylnych wcześniejszych opiniach, to właśnie ich niepokoje, uwagi dotyczące rozwoju i zachowania dziecka, w większości przypadków precyzyjnie opisane i uzasadnione, znacznie przyspieszają wykrywanie zaburzeń $u$ ich dziecka, przyczyniając się do postawienia trafnej diagnozy, a także wyboru stosownej terapii dla dziecka ${ }^{54}$.

Powszechnie wiadomo, że udział rodziców w procesie wczesnej interwencji dziecka zagrożonego autyzmem jest decydujący i niezbędny. Badania pokazują, że terapie prowadzone przez rodziców mogą zwiększyć zdolności werbalne i niewerbalne dzieci oraz umiejętności związane z zabawą, a także poprawiać ich wzajemne relacje ${ }^{55}$.

52 S.J. Rogers, G. Dawson, L.A. Vismara, op. cit., s. 68; R. Palomo, M. Belinchón, S. Ozonoff, Autism and family home movies: a comprehensive review, "Journal of Developmental and Behavioral Pediatrics" 2006, nr 27 (2, Suppl.), s. 59-68.

53 M. Skórczyńska, op. cit., s. 56.

${ }^{54}$ H. Jaklewicz, op. cit., s. 117; E. Pisula, Autyzm u dzieci..., s. 51; E. Pisula, Mate dziecko..., s. 62; J.L. Crane J.L., A. Winsler, Early Autism Detection, Implications for Pediatric Practice and Public Policy, "Journal of Disability Policy Studies" 2008, vol. 18, 4, s. 245-253.

55 S.J. Rogers, G. Dawson, L.A. Vismara, op. cit., s. 76-80, s. 57; S.J. Rogers, G. Dawson, op. cit., s. 57. 


\section{Budowanie relacji dziecka ze spektrum autyzmu w kontakcie z bliskimi - przywiązanie}

Już w latach 40. XX w. Leo Kanner jako pierwszy zauważył, że dzieci dotknięte autyzmem przychodzą na świat $\mathrm{z}$ „wrodzoną nieumiejętnością tworzenia zwykłych, biologicznie uwarunkowanych kontaktów z ludźmi"56. Jego zdaniem fundamentalnym objawem autyzmu jest „niezdolność tych dzieci do odnoszenia się w zwykły sposób do ludzi i sytuacji” 57 . Autor wskazywał: „że już od samego początku obecna jest u nich ekstremalna autystyczna samotność, która gdy tylko jest to możliwe, gardzi, ignoruje, odrzuca wszystko, co przychodzi do dziecka z zewnątrz" ${ }^{58}$. Podkreślał także w opisach klinicznych swoich pacjentów brak uwagi kierowanej na ludzi, brak świadomości uczuć innych ludzi, traktowanie ich, jakby byli przedmiotami nieożywionymi oraz na "obojętność”, jaką przejawiają te dzieci względem swoich najbliższych. Sugerował, że nie następuje $u$ nich wczesne tworzenie się więzi czy relacji przywiązania i że właśnie ten fakt należy uznać za jeden z najważniejszych przejawów autyzmu ${ }^{59}$. Współczesne rozważania i badania nad przywiązaniem $\mathrm{w}$ autyzmie nie potwierdzają jednoznacznie charakteru takiej formy deficytu, na jaki wskazywał L. Kanner. Przez wiele lat pogląd ten uległ znacznej weryfikacji, a uzyskane wyniki badań wskazały na złożoność tego zjawiska ${ }^{60}$.

System przywiązania jest elementem genetycznego zaprogramowania człowieka, warunkującym wystąpienie w sytuacjach zagrożenia (lub braku poczucia bezpieczeństwa) trzech typowych

${ }^{56}$ L. Kanner, L., Autistic disturbances of affective contact, "Nervous child" 1943, nr 2, s. 242; J. Blacher, L. Christensen, Sowing The Seeds of The Autism Field: Leo Kanner (1943), “Intellectual And Developmental Disabilities" 2011, Vol. 49, nr 3, 172-191.

57 Ibidem, s. 242

58 Ibidem.

${ }^{59}$ U. Frith, Autyzm. Wyjaśnienie tajemnicy, Gdańskie Wydawnictwo Psychologiczne, Gdańsk 2008, s. 136.

${ }^{60}$ E. Pisula, Rodzice dzieci z autyzmem, Wydawnictwo PWN, Warszawa 2012, s. 86 . 
zachowań: poszukiwanie, monitorowanie utrzymywania bliskości z chroniącą figurą (najczęściej matką) przywiązania, wykorzystywanie figury przywiązania jako bezpiecznej bazy oraz uciekanie się do figury przywiązania jako „bezpieczniej przystani” w chwilach zagrożenia lub niepokoju. Wśród reakcji świadczących o przywiązaniu dziecka do opiekuna można wyróżnić zachowania sygnalizacyjne (płacz, uśmiech, gaworzenie) oraz zachowania polegające na dążeniu do bliskości (przywieranie do dorosłego, podążanie za nim, wyciąganie rąk) ${ }^{61}$. Według Mary D. Salter Ainsworth ${ }^{62}$ przywiązanie to coś więcej niż tylko sympatia lub oddanie, to głęboka więź emocjonalna tworząca się między dwiema jednostkami, która łączy je razem w przestrzeni i wykazuje trwałość w czasie ${ }^{63}$.

Badania nad przywiązaniem mają w odniesieniu do autyzmu znaczenie szczególne, bywa on bowiem traktowany jako zaburzenie więzi. Wobec znanego z obserwacji faktu, że niektóre dzieci z autyzmem sprawiają wrażenie całkowicie obojętnych na obecność rodzica, inne zaś przejawiają wyraźne oznaki przywiązania, a nawet emocjonalnego uzależnienia od bliskiego opiekuna, trudno ustalić jednoliniowy profil relacji rodzic - dziecko w całej populacji dzieci ze spektrum autyzmu. Ponadto różnice w ekspresji przywiązania nie są równoznaczne ani $\mathrm{z}$ brakiem zdolności do tworzenia więzi emocjonalnych, ani z określonym charakterem więzi. Ponieważ rozwój społeczno-emocjonalny tych dzieci jest znacznie zaburzony, to pojawia się także problem, które zachowania dziecka należy uznać za główne wskaźniki przywiązania typowe dla tej populacji, a które rozpatrywać wyłącznie jako pochodną deficytów typowych dla autyzmu ${ }^{64}$. Chodzi tutaj szczególnie o takie zachowania jak: kontakt fizyczny i wzrokowy, współdzielenie uwagi, komunikowanie się intencjonalne. Dzieci $\mathrm{z}$ autyzmem w obcej sytuacji rzadziej komunikują się z bliskim opiekunem, zarówno werbalnie, jak i nie-

${ }^{61}$ M. Piszczek, op. cit., s. 11.

62 M.D.S. Ainsworth, Attachment as related to mother - infant interaction, "Advances in the Study of Behavior"1979, nr 9, s. 2-51.

63 H.R. Schaffer, op. cit., s. 165.

${ }^{64}$ E. Pisula, Autyzm i przywiazanie..., s. 52-53. 
werbalnie, rzadziej też dzielą się swoimi zainteresowaniami jakimś obiektem, co jest związane głównie z defektem tworzenia wspólnego pola uwagi. Nie potrafią ukierunkować uwagi innej osoby na określone obiekty lub zdarzenia, a także monitorować uwagi innej osoby oraz zwracać uwagę na to, co osoba chce pokazać65. Nie widzą związku między patrzeniem na coś a pragnieniem posiadania tego, manipulowania tym $\mathrm{z}$ ciekawości66. Trudności sprawia im odczytywanie treści informacji zawartych w kierunku patrzenia67. Zaburzenia zdolności tworzenia wspólnej uwagi u osób z autyzem pozostają w ścisłym związku z niezdolnością odczytywania stanów umysłu, odróżniania tego, o czym same myślą od tego, o czym myśli ktoś inny oraz łączą się z brakiem umiejętnosći uczestnictwa $\mathrm{w}$ naprzemiennych interakcjach społecznych i zaburzeniach w komunikowaniu się intencjonalnym ${ }^{68}$. Poprawne rozumienie dzielenia wspólnej uwagi rozwija się przecież w wyniku licznych interakcji z najbliższymi osobami i wymaga świadomości zakresu orientacji w otoczeniu partnerów interakcji społecznej69.

Brak albo minimalny kontakt wzrokowy, dążenie do utrzymania dystansu fizycznego, niechęć do czułych gestów ze strony bliskiej osoby, a szczególnie brak poszukiwania pocieszenia u innych osób w trudnych dla siebie sytuacjach sprawiają, że nie jest możliwe, by dzieci te przejawiały przywiązanie w taki sam sposób jak ich rówieśnicy. Nie wydają się być zainteresowane nawiązywaniem kontaktu wzrokowego i patrzeniem na twarze ludzi w celu odczytywania ich potrzeb, pragnień i intencji. Wydaje się dla nich niezrozumiałe, że o znaczeniu spojrzenia decyduje stan umysłu podzielo-

65 E. Pisula, Autyzm u dzieci..., s. 80.

66 E. Pisula, Autyzm i przywiazanie..., s. 48.

67 K. Markiewicz, op. cit., s. 99.

${ }^{68}$ E. Pisula, Rodzice $i$ rodzeństwo dzieci z zaburzeniami rozwoju, Wydawnictwo Uniwersytetu Warszawskiego, Warszawa 2007, s. 48; U. Frith, op. cit., s. 131-132.

${ }^{69}$ M. Talarowska i in., op. cit., s. 109; S.R. Leekam, C. Ramsden, Dyadic orienting and joint attention in preschool children with aitism, "Journal of Autism and Developmental Disorders" 2006, nr 36, s. 185-169; H.H. Schertz, S.L. Odom, Promoting joint attention in toddlers with autism: a parent- mediated developmental model, "Journal of Autism and Developmental Disorders" 2007, nr 37(8), s. 1562-1575. 
ny przez dwie osoby ${ }^{70}$. Dla dzieci, które nie rozumieją stanów umysłu leżących u podstaw tego rodzaju spojrzeń, kontakt wzrokowy jest nieistotny i nie spełnia funkcji społecznej oraz komunikacyjnej (intencjonalnej) ${ }^{71}$.

Ponadto dzieci z tej grupy zaburzeń rzadko okazują uczucia i prawie nie czynią tego tak jak inni. Nie szukają pomocy u swoich bliskich osób, a często sprawiają wrażenie nieświadomych, że jest to w ogóle możliwe. Nie potrafią współpracować z innymi ludźmi, a szczególnie z bliskimi rodzicami/opiekunami. Przejawiają specyficzne wzorce eksploracji, zależne raczej od nietypowego odbioru wrażeń zmysłowych niż od obecności opiekuna. Wiele dzieci ze spektrum autyzmu nie różnicuje bliskich i obcych im osób, traktując je w taki sam sposób. Wszystko to sprawia, że ich zachowanie trudno zaliczyć do modelowego wzorca przywiązania. Należy zatem podkreślić, że aby analizować i wnioskować na temat przywiązania dzieci ze spektrum autyzmu, niezbędne jest uwzględnienie charakterystycznych problemów w ich rozwoju społecznym i emocjonalnym ${ }^{72}$.

$\mathrm{W}$ badaniach nad przywiązaniem $\mathrm{u}$ dzieci ze spektrum autyzmu dominuje paradygmat obcej sytuacji. Głównym celem tej eksperymentalnej procedury - TESTU OBCEJ SYTUACJI (Strange Situation Test) jest zmierzenie bezpiecznego i pozabezpiecznego przywiązania emocjonalnego dzieci do rodziców ${ }^{73}$. Za główne kryteria z punktu widzenia możliwości wnioskowania na temat przywiązania dziecka przyjmuje się: zachowanie dziecka $\mathrm{w}$ wywołującej lęk sytuacji separacji od matki oraz $\mathrm{w}$ sytuacji jej powrotu, a także różnice $\mathrm{w}$ jego zachowaniu wobec matki i wobec obcej kobiety. Taki sposób pomiaru jakości związku rodzic - dziecko w warunkach kontrolowanych pozwala zaobserwować reakcję dziecka na obecność rodzica, jak i na jego brak oraz reakcję dziecka na pojawienie się obcej osoby ${ }^{74}$.

70 U. Frith, op. cit., s. 134.

71 S. Baron-Cohen, op. cit.

72 E. Pisula, Autyzm i przywiazanie..., s. 53.

${ }^{73}$ M.D.S. Ainsworth, op. cit., s. 2-51.

74 S. Gerhardt, Znaczenie miłości. Jak uczucia wpływaja na rozwój mózgu, Wydawnictwo Uniwersytetu Jagiellońskiego, Kraków 2010, s. 4. 
Wyniki wielu przeprowadzonych badań wskazują, że dzieci $\mathrm{z}$ autyzmem przejawiają $\mathrm{w}$ zachowaniu oznaki przywiązania, a w sytuacji stresu szukają komfortu u swoich bliskich opiekunów (badania: C. Dissanayake i S.A. Crossley z 1996 r.; S. J. Rogers, S. Ozonoff i C. Maslin-Cole z 1991 r.; A H. Rutgers z zespołem z 2004 r.) $)^{75}$. Zaobserwowano występowanie wszystkich wzorów przywiązania, tj. ufnego, unikowego i ambiwalentnego, a także zdezorganizowanego. Nie ma natomiast zgodności co do rozkładu częstości występowania tych wzorów. W niektórych badaniach wykazano, że pojawiają się one $\mathrm{w}$ podobnych proporcjach jak $\mathrm{w}$ populacji dzieci zdrowych, a ponad $50 \%$ tych dzieci manifestuje oznaki bezpiecznego przywiązania. Rzadziej zaobserwowano występowanie ufnego przywiązania, natomiast proporcja dzieci ze zdezorganizowanym przywiązaniem jest $\mathrm{w}$ tej populacji relatywnie wysoka. Współcześnie dominuje pogląd, że dzieci ze spektrum autyzmu są zdolne do formowania ufnego przywiązania, a różnice miedzy nimi a ich rozwijającymi się prawidłowo rówieśnikami odnoszą się przede wszystkim do jego ekspresji emocjonalnej (badania: A.H. Rutgers z zespołem z 2004 r. oraz F. Naber z zespołem z 2007 r. ${ }^{76}$. Problemy $\mathrm{z}$ regulacją emocji mogą odgrywać istotną rolę $\mathrm{w}$ rozwoju przywiązania w całej populacji dzieci ze spektrum autyzmu ${ }^{77}$.

Za występowaniem jakichkolwiek oznak przywiązania dzieci $\mathrm{z}$ autyzmem $\mathrm{w}$ relacji $\mathrm{z}$ matkami przemawia wynik eksperymentu przeprowadzonego przez C. Dissanayake i S.A. Crossley, w którym uczestniczyły dzieci z autyzmem $w$ wieku od 2 do 5 lat. Ich zachowanie porównywano $\mathrm{z}$ zachowaniem dzieci bez autyzmu $\mathrm{w}$ zbliżonym wieku umysłowym, ale upośledzonych pod względem zdolności do uczenia się. Eksperyment polegał na tym, że dziecko spędza trochę czasu z matką w dowolnej zabawie. Kolejno matka wychodzi i z dzieckiem pozostaje obca osoba. Po krótkiej chwili matka wraca. Wskaźnikiem przywiązania jest wzrost spontanicznych reakcji emocjonalnych dziecka z matką po jej powrocie. Szczególnie istotne jest

${ }^{75}$ E. Pisula, Rodzice dzieci..., s. 86.

76 Ibidem, s. 86.

77 E. Pisula, Autyzm i przywiazanie..., s. 61. 
zaniepokojenie dziecka, gdy matka opuszcza pomieszczenie, a zadowolenie, gdy wraca do dziecka. Dzieci z obu grup reagowały w podobny sposób, gdy zostawały same z obcą osobą, a także po powrocie matki. Przy ponownym spotkaniu wszystkie dzieci wykazywały znaczny wzrost zachowań społecznych skierowanych do matki. Możemy zatem wnioskować, że dzieci z autyzmem przejawiają zachowania świadczące o przywiązaniu do bliskich. Jednak ich zachowanie wobec matki i osoby obcej jest zróżnicowane. Reagują na separację i na powrót matki, poszukują oparcia w matce $w$ sytuacji zagrożenia. Problem dotyczy jednak nietypowości oznak przywiązania. Szczególnie widoczny był rzadki kontakt wzrokowy, niechęć do kontaktu fizycznego, współdzielenia uwagi i form komunikacji $\mathrm{z}$ matką ${ }^{78}$. Tego typu nieprawidłowości w sferze przywiązania przekładają się na ich funkcjonowanie społeczno-emocjonalne.

Nie jest zaskakujące, że dla rozwoju umiejętności społecznych i kompetencji emocjonalnej oraz dla teorii umysłu najbardziej pożądanym jest styl bezpieczny. Jest on uważany za wzorcowy, a także za taki, który pozwala na osiągnięcie prawidłowego funkcjonowania w przyszłości ${ }^{79}$. Dzieci ze spektrum autyzmu, które wykształciły ten rodzaj przywiązania, mają większą łatwość regulacji emocji, skutecznie potrafią obniżać własne napięcie, trafnie rozpoznają stany emocjonalne $\mathrm{u}$ siebie $\mathrm{i} u$ innych, mają optymistyczniejsze nastawienie do ludzi i prezentują pozytywną atrybucję wydarzeń i intencji innych ludzi. Większość badaczy przywiązania relacji matka - dziecko uważa, że jest to także zasługa samych matek, które to nawiązują ze swoimi dziećmi bezpieczne więzi, traktują je bardziej podmiotowo, uważnie odczytują ich potrzeby, emocje i pragnienia. Ponadto zauważono, że dzieci bezpiecznie przywiązane do opiekunów zdecydowanie bardziej im ufają, traktując ich jako pewne źródło informacji niż dzieci o unikającym czy ambiwalentnym stylu przywiązania (badania: K.H. Corriveau z 2009 r.) ${ }^{80}$. Dzięki

78 Ibidem, s. 62.

79 J. Smogorzewska, G. Szumski, Rozwijanie kompetencji społecznych dzieci przedszkolnych. Teoria - Metodyka - Efekty, Wydawnictwo PWN, Warszawa 2015, s. 24.

80 J. Smogorzewska, G. Szumski, op. cit., s. 25. 
relacjom opartym na poczuciu bezpiecznego przywiązania, dziecko nabywa zdolności do mentalizacji i regulacji afektu. Taką relację cechuje również intersubiektywność, ponieważ dziecko poznaje siebie $\mathrm{w}$ procesie bycia poznawanym przez bliskiego opiekuna ${ }^{81}$.

Stwierdzono również, że istnieje związek miedzy wrażliwością matki podczas interakcji a wzorem przywiązania u dziecka. W rozumieniu M. Ainsworth wrażliwość macierzyńska (lub szerzej rodzicielska), stanowi szerszą dostępność opiekuna, jego zdolność do odbioru, interpretowania i adekwatnego reagowania na sygnały obecne w zachowaniu dziecka, a także gotowość do współdziałania z nim, akceptacji i oferowania komfortowej dla niego bliskości ${ }^{82}$. L. Capps i in. ${ }^{83}$ stwierdzili, że matki dzieci ufnie przywiązanych charakteryzowały się większą wrażliwością niż matki dzieci prezentujących inne wzorce przywiązania. Związek taki w grupie dzieci ze spektrum autyzmu został potwierdzony w wielu badaniach (badania: N. Koren-Karie z zespołem z 2009 r.; M.H. van IJzendoor z zespołem z 2007 r.). Zaobserwowano ponadto, że dzieci ze spektrum autyzmu, których rodzice mieli reprezentację bezpiecznych wzorów przywiązania, lepiej radziły sobie z inicjowaniem komunikacji za pomocą gestów i z odpowiadaniem na takie sygnały podczas interakcji presymbolicznych, a także częściej angażowały się w myślenie wyobrażeniowe i zabawę symboliczną oraz znacznie lepiej komunikowały się werbalnie ${ }^{84}$. Z badań wynika ponadto, że stałe, aktywne zainteresowanie matki tym, co robi dziecko, co przyciąga jego uwage i komunikowanie tego dziecku, "odpowiadanie” na zachowanie dziecka, niekoniecznie adresowane do dorosłego, jest po prostu wprowadzeniem dziecka w proces interakcyjnej wymiany reakcji i interpersonalnego rozwoju ${ }^{85}$. Zależność ta ma charakter oczywisty

${ }^{81}$ M. Piszczek, op. cit., s. 14.

82 J. Wycisk, Rozwój systemu sprawowania opieki u matek w świetle teorii przywiąania społecznego, „Psychologia Rozwojowa” 2012, tom 17, nr 2, s. 16.

${ }^{83}$ L. Capps i in., Attachment security in children with autism. "Development and Psychopathology" 1994, nr 6(2), s. 249-261.

84 E. Pisula, Rodzice dzieci..., s. 87.

85 B. Bokus, Nawiązywanie interakcji społecznych przez mate dziecko, [w:] Monografie Psychologiczne, red. T. Tomaszewski, Zakład Narodowy Imienia Ossolińskich, Wy- 
i uniwersalny - przywiązanie to proces interakcyjny ${ }^{86}$ (badania nad modelem interpersonalnego rozwoju w autyzmie: S.J. Rogers i B.F. Pennington z 1991 r., M. Carpenter, i M. Tomasello z 2000 r.).

Powstanie prawidłowych więzi emocjonalnych w relacji dziecko - rodzic nie zależy wyłącznie od starań rodziców. Potrzebna jest do tego także aktywność własna dziecka. Powszechnie wiadomo, że patologiczne zaburzenia emocjonalne $\mathrm{u}$ dziecka $\mathrm{z}$ autyzmem stają się źródłem ich negatywnych emocji: złości, lęku, zmartwienia u rodziców. Za najboleśniejsze elementy zaburzenia u tych dzieci rodzice podają: problemy $z$ werbalizacją, niejednolitość i nieprzewidywalność zachowań, obojętność na bliskość i miłość rodzica, sprzeczności na poziomie różnych funkcji poznawczych, brak wyrażania i komunikowania potrzeb, ciągły stan niepokoju. Rodzicielski stres potęgują występujące $\mathrm{u}$ dziecka $\mathrm{z}$ autyzmem specyficzne deficyty w zakresie ekspresji emocji, zdecydowanie zaburzające empatię między nim a bliskimi ${ }^{87}$.

Nasilenie tego stresu w dużej mierze zależy od wieku dziecka, jego poziomu rozwoju, stopnia nasilenia zaburzeń (ruchowych, komunikacyjnych, emocjonalnych, społecznych), tzw. "trudnych” zachowań, stopnia niepełnosprawności intelektualnej, wieku, zdolności do adaptacji oraz ogólnej sumy wymagań, jakim sprostać musi rodzic w związku z funkcjonowaniem dziecka. Choć nie można określić prostego związku między stresem rodziców a pojedynczo analizowanymi aspektami rozwoju dziecka, np. zdolnością do komunikowania się. Dopiero występowanie u dziecka kilku zaburzeń równocześnie powoduje wyraźny wzrost poziomu stresu u rodziców ${ }^{88}$.

Wszelkie nietypowe zachowania dziecka ze spektrum autyzmu wymagają od rodziców adaptacji. Będzie się to wiązać z konieczno-

dawnictwo Polskiej Akademii Nauk, Wrocław, Warszawa, Kraków, Gdańsk, Łódź 1984, s. 12.

86 E. Pisula, Autyzm i przywiazzanie..., s. 62.

${ }^{87}$ E. Pisula, Stres rodzicielski zwiazany z wychowaniem dzieci autystycznych i z zespołem Dawna, "Psychologia Wychowawcza”, 1993, nr 1, s. 130-138; E. Pisula, Rodzice dzieci..., s. 84-85.

88 E. Pisula, Rodzice i rodzeństwo..., s. 46. 
ścią wypracowania przez nich określonych strategii postępowania oraz stylów przywiązania, uwzględniając specyficzną aktywność dziecka. Zaobserwowano, że zachowanie rodziców wobec dzieci $\mathrm{z}$ autyzmem podlega pewnemu szczególnemu wzorowi. Łączy się on z większym kontrolowaniem dzieci, częstszym wydawaniem poleceń, a także z dążeniem do tego, by dzieci stały się uległe. Rodzice też rzadziej się z nimi bawią. Nawet jeżeli inicjują interakcję z dzieckiem, to jednocześnie przy tym formułują więcej nakazów i częściej kontrolują zachowanie dziecka. Może to stanowić próbę dążenia do „normalności” dziecka, czyli wywołanie u niego zachowań zgodnych z ich oczekiwaniami. Jeżeli chodzi o dzieci ze spektrum autyzmu jako parterów interakcji społeczno-emocjonalnej, to zdecydowanie cechuje je mniejsza aktywność. Niezbyt często inicjują kontakt, rzadziej też akceptują propozycje partnera i z nim współdziałają. Rzadziej się uśmiechają, patrzą na niego, zbliżają się oraz częściej okazują emocje negatywne. Niepowodzeniem kończą się próby ukierunkowania jego uwagi na konkretny obiekt, a tym bardziej przenoszenia uwagi z jednego przedmiotu na inny. Co $\mathrm{u}$ rodzica wywołuje wrażenie, że nie jest ono zainteresowane tym, co matka mu proponuje. To zdecydowanie doprowadza u rodziców do doświadczenia stresu, frustracji. Wiele obserwacji badań potwierdziło, iż wraz z wiekiem dziecka częstotliwość jego kontaktów z rodzicem maleje. Nie jest to jednak równoznaczne z gorszą jakością tych kontaktów społecznych. W miarę rozwoju dziecka wzrasta bowiem responsywność matek. Wraz z wiekiem dziecka uczą się one dokładniej odczytywać dziecięce komunikaty, wypracowują sposoby interpretacji ich znaczenia i coraz lepiej komunikują się z dzieckiem. Rodzice uczą się jak rozumieć swoje dziecko, jak komunikować się z nim i jak odczytywać jego zachowanie, co zdecydowanie poszerza ich kompetencje rodzicielskie ${ }^{89}$.

Z kolei dziecko ze spektrum autyzmu w wyniku nieograniczonej liczby interakcji z bliskim opiekunem, ożywionych ruchów, uśmiechów, przyjaznych gestów o zabarwieniu emocjonalnym uczy

${ }^{89}$ E. Pisula, Autyzm i przywiazanie..., s. 11-19. 
się odczytywać społeczne i emocjonalne wskazówki innych i reagować na nie oraz przekazywać własne sygnały. Te znaczące schematy, obejmujące naprzemienne odczytywanie i reagowanie na sygnały emocjonalne, pozwalają dziecku zacząć kształtowanie własnych schematów społeczno-emocjonalnych, norm kulturowych i zasad typowych dla jego rodziny oraz środowiska w którym żyje. Z kolei umiejętność odczytywania schematów innych ludzi i kształtowanie samoświadomości w wyniku rozpoznawania własnych schematów jest podstawą rozwoju teorii umysłu, czyli odczytywania przekonań, pragnień i intencji innych ludzi. Umiejętność ta jest o tyle konieczna, by nauczyć małe dziecko wiedzy, kiedy i jak ma oczekiwać różnych reakcji bliskiego opiekuna albo zdawać sobie sprawę z tego, czym jest odczuwanie miłości, bliskości, czułości $\mathrm{i}$ radości bycia $\mathrm{w}$ relacji $\mathrm{z}$ rodzicem/opiekunem ${ }^{90}$. Bliska relacja oparta na otwartości, wyczuleniu i wrażliwości ze strony rodzica jest podstawą, by dziecko mogło osiągnąć jak najwyższe umiejętności emocjonalno-społeczne $\mathrm{w}$ relacjach z ludźmi ${ }^{91}$.

\section{Bibliografia}

Ainsworth M.D.S., Attachment as related to mother - infant interaction, "Advances in the Study of Behavior"1979, nr 9.

Attwood T., Zespót Aspergera, Wydawnictwo Zysk i S-ka, Poznań 2006.

Ball J., Autyzm a wczesna interwencja. Rzeczowe pytania, życiowe odpowiedzi, Wydawnictwo Harmonia Universalis, Gdańsk 2016.

Baron-Cohen S., Mindblindness: An essay on autism and theory of mind, Cambridge Mass., MIT Press, London 1995.

Blacher J., Christensen L., Sowing The Seeds of The Autism Field: Leo Kanner (1943), "Intellectual And Developmental Disabilities" 2011, Vol. 49, nr 3.

Błeszyński J., Autyzm a niepetnosprawność intelektualna i opóźnienie w rozwoju. Skala Oceny Zachowań Autystycznych, Wydawnictwo Harmonia Universalis, Gdańsk 2011.

Bokus B., Nawiązywanie interakcji społecznych przez małe dziecko, [w:] Monografie Psychologiczne, red. T. Tomaszewski, Zakład Narodowy Imienia Ossolińskich, Wy-

90 S.L. Greenspan, S. Wieder, op. cit., s. 408-410.

91 S.J. Rogers, G. Dawson, L.A. Vismara, op. cit., s. 16-17. 
dawnictwo Polskiej Akademii Nauk, Wrocław, Warszawa, Kraków, Gdańsk, Łódź 1984.

Capps L., Sigman M., Mundy P., Attachment security in children with autism. „Development and Psychopathology" 1994, nr 6(2).

Cotugno A.J., Terapia grupowa dla dzieci z zaburzeniami ze spectrum autyzmu. Rozwijanie kompetencji $i$ umiejętności społecznych, Wydawnictwo Fraszka Edukacyjna, Warszawa 2011.

Crane J.L., Winsler A., Early Autism Detection, Implications for Pediatric Practice and Public Policy, "Journal of Disability Policy Studies" 2008, vol. 18, 4.

Dawson G., Osterling J., Early recognition of children with autism: A stady of first birthday home videotapes, "Journal of Autism and Developmental Disorders" 1994, no. 24.

Frith U., Autyzm. Wyjaśnienie tajemnicy, Gdańskie Wydawnictwo Psychologiczne, Gdańsk 2008.

Gałkowski T., Usprawnianie dziecka autystycznego w rodzinie, Wydawnictwo PTWK, Warszawa 1980.

Gerhardt S., Znaczenie miłości. Jak uczucia wpływaja na rozwój mózgu, Wydawnictwo Uniwersytetu Jagiellońskiego, Kraków 2010.

Greenspan S.L., Wieder S., Dotrzeć do dziecka z autyzmem. Jak pomóc dzieciom nawiązywać relacje, komunikować się i myśleć. Metoda Floortime, Wydawnictwo Uniwersytetu Jagiellońskiego, Kraków 2014.

Jagielska G., Objawy autyzmu dziecięcego, [w:] Autyzm i zespół Aspergera, red. J. Komender, G. Jagielska, A. Bryńska, Wydawnictwo Lekarskie PZWL, Warszawa 2009.

Jaklewicz H., Autyzm dziecięcy, [w:] Psychiatria wieku rozwojowego, red. A. Popielarska, M. Popielarska, Wydawnictwo Lekarskie PZWL, Warszawa 2000.

Kanner L., Autistic disturbances of affective contact, "Nervous child" 1943, nr 2.

Leekam S.R., Ramsden C., Dyadic orienting and joint attention in preschool children with aitism, "Journal of Autism and Developmental Disorders" 2006, nr 36

Markiewicz K., Charakterystyka zmian w rozwoju umysłowym dzieci autystycznych, Wydawnictwo Uniwersytetu Marii Curie-Skłodowskiej, Lublin 2007

Morrison J., DSM-5 Bez Tajemnic. Praktyczny przewodnik dla klinicystów, Wydawnictwo Uniwersytetu Jagiellońskiego, Kraków 2016.

Nason B., Porozmawiajmy o autyzmie Przewodnik dla rodziców i specjalistów, Wydawnictwo Uniwersytetu Jagiellońskiego, Kraków 2017.

Olechnowicz H., Wiktorowicz R., Dziecko z autyzmem, Wyzwalanie potencjatu rozwojowego, Wydawnictwo PWN, Warszawa 2012.

Ozonoff S., Dawson G., McPartland J.C., Wysokofunkcjonujące dzieci ze spektrum autyzmu. Poradnik dla rodziców, Wydawnictwo Uniwersytet Jagielloński, Kraków 2015.

Palomo R., Belinchón M., Ozonoff S., Autism and family home movies: a comprehensive review, "Journal of Developmental and Behavioral Pediatrics" 2006, no 27 (2, Suppl.). 
Pisula E., Autyzm i przywiązanie. Studia nad interakcjami dzieci z autyzmem i ich matek, Gdańskie Wydawnictwo Psychologiczne, Gdańsk 2003.

Pisula E., Autyzm u dzieci. Diagnoza, klasyfikacja, etiologia, Wydawnictwo PWN, Warszawa 2000.

Pisula E., Małe dziecko z autyzmem. Diagnoza i Terapia, Gdańskie Wydawnictwo Psychologiczne, Gdańsk 2005.

Pisula E., Od badań mózgu do praktyki psychologicznej AUTYZM, Wydawnictwo GWP, Sopot 2012.

Pisula E., Rodzice dzieci z autyzmem, Wydawnictwo PWN, Warszawa 2012.

Pisula E., Rodzice i rodzeństwo dzieci z zaburzeniami rozwoju, Wydawnictwo Uniwersytetu Warszawskiego, Warszawa 2007.

Pisula E., Stres rodzicielski zwiazany $z$ wychowaniem dzieci autystycznych $i$ z zespołem Dawna, „Psychologia Wychowawcza” 1993, nr 1.

Pisula E., Wspomaganie osób z zaburzeniami należącymi do autystycznego spektrum w perspektywie psychopatologii rozwojowej, [w:] Psychologia rozwoju człowieka, red. J. Trempała, Wydawnictwo PWN, Warszawa 2011.

Piszczek M., Autyści. Indywidualne $i$ grupowe metody terapii. Zajęcia adresowane dla Rodziców, Wydawnictwo STECKO, Warszawa 2014.

Randall P., Parker J., Autyzm. Jak pomóc rodzinie, Gdańskie Wydawnictwo Psychologiczne, Sopot 2010.

Rogers S.J., Dawson G., Early Start Denver Model dla matych dzieci z autyzmem. Wspieranie komunikacji, uczenia się i rozwoju społecznego, Wydawnictwo Fundacja Rozwiązać Autyzm, Warszawa 2015.

Rogers S.J., Dawson G., Vismara L.A. Metoda wczesnego startu dla dziecka z autyzmem (ESDM). Jak wykorzystać codzienne aktywności, aby pomóc dzieciom tworzyć więzi, komunikować się i uczyć, Wydawnictwo Uniwersytetu Jagiellońskiego, Kraków 2015.

Rybka A, Garncarz A., Stymulowanie rozwoju emocjonalnego u osób z autyzmem, [w:] Kompleksowe wspomaganie rozwoju uczniów z autyzmem i zaburzeniami pokrewnymi, red. J. Kossewska, Oficyna Wydawnicza „Impuls”, Kraków 2009.

Rynkiewicz A., Zespót Aspergera. Inny mózg. Inny umyst, Wydawnictwo Harmonia, Gdańsk 2009.

Saarni C., Kompetencja emocjonalna i samoregulacja w dzieciństwie, [w:] Rozwój emocjonalny a inteligencja emocjonalna, red. P. Salovey, D. Sluyter, Dom Wydawniczy REBIS, Poznań 1999.

Schaffer H.R., Psychologia dziecka, Wydawnictwo PWN, Warszawa 2009.

Schertz H.H., Odom S.L., Promoting joint attention in toddlers with autism: a parentmediated developmental model, "Journal of Autism and Developmental Disorders" 2007, nr 37(8).

Senator D., Przejawy autyzmu w pierwszym roku życia, „Pediatria Polska” 2006, nr 2. 
Skórczyńska M., Wczesne diagnozowanie autyzmu - perspektywy i dylematy, [w:] Autyzm Na granicy zrozumienia, red. B. Winczura, Oficyna Wydawnicza „Impuls”, Kraków 2009.

Smogorzewska J., Szumski G., Rozwijanie kompetencji społecznych dzieci przedszkolnych. Teoria - Metodyka - Efekty, Wydawnictwo PWN, Warszawa 2015.

Talarowska M., Florkowski A., Gałecki P., Zboralski K., Psychologiczne koncepcje rozwoju autyzmu, [w:] Autyzm - epidemiologia, diagnoza i terapia, red. T. Pietras, A. Witusik, P. Gałecki, Wydawnictwo Continuo, Wrocław 2010.

Wiekiera E., Strategia postępowania z dziećmi autystycznymi, Przekład z "Engagement", Poradnik praktyczny dla rodziców, Wydawnicwo Krajowe Towarzystwo Autyzmu Oddział w Krakowie, Kraków 1995.

Wing L., Zwiazek między zespotom Aspergera i autyzmem Kannera, [w:] Autyzm i zespót Aspergera, red. U. Frith, Wydawnictwo Lekarskie PZWL, Warszawa 2005.

Wolski A., Diagnoza autyzmu u matego dziecka - implikacje do pracy $w$ rodzinie, "Rewalidacja. Czasopismo dla nauczycieli i terapeutów" 2010, nr 2 (28).

Wolski A., Dominujace i drugorzędne kryteria diagnostyczne - ich struktura u dzieci, u których zdiagnozowano autyzm, [w:] Edukacja i Rehabilitacja Osób Niepetnosprawnych OBLICZA TERAPII, Pedagogika Specjalna - koncepcje i rzeczywistość, Tom IX, red. T. Żółkowska, M. Wlazło, Wydawnictwo Naukowe WH MINERWA, Szczecin 2013.

Wycisk J., Rozwój systemu sprawowania opieki u matek w świetle teorii przywiazania społecznego, „Psychologia Rozwojowa” 2012, tom 17, nr 2. 